\title{
Affirming the abilities of new teachers: A teacher induction project within the Golden Horseshoe Learning Consortium
}

\author{
Lorenzo Cherubini: Brock University, Canada \\ Julian Kitchen: Brock University, Canada
}

\begin{abstract}
This paper presents a partnership among Brock University's Faculty of Education, the Ontario College of Teachers and six school boards that resulted in a teacher induction project conceptualized to enable new teachers to self-affirm their professional capacities as teacher leaders. The new teacher participants from 6 district school boards in southern Ontario were engaged in critical thinking and retrospective analysis with experienced teacher mentors from these same school boards. The outcomes of the project suggest that the induction model validated new teachers' meaningful contributions to their students and schools and heightened their sense of self-empowerment as reflective and active teacher leaders.
\end{abstract}

\section{Conceptual Framework}

Teacher induction is in fact a current and relevant educational initiative across North America. Darling-Hammond (2006) states that teachers' abilities directly impact upon student achievement and educational improvement (see, also, Cochran-Smith, 2006). Effective teacher induction programs are crucial in terms of retaining teachers and in improving their practice (Fulton, Yoon, \& Lee, 2005; Smith \& Ingersoll, 2004). The literature, however, suggests that new teachers are often not equipped with the necessary professional support necessary to make the successful transition from pre- to in-service teacher (Brock \& Grady, 1997; Danielson, 2002). Consider as well the high proportion of new teachers who leave the profession in the first three to five years $(46 \%$ in the United States) and the fact that teacher retention is more aligned to the nature of the first teaching experience than it is to an individual's academic proficiency or to the quality of their professional teacher education program (see Nielsen, Lundmark, Barry, \& Addison, 2006).

The research context was approached with an understanding of the variable conditions that define teacher induction practices (see, for example, Weiss \& Weiss, 1999). Induction involves the formal and comprehensive process of initiating new teachers into the teaching profession (Bullough, 1988; Duncan-Poiter, 2005; Renard, 2003). Induction programs assist with the transition between preservice education and the responsibilities of being a first year classroom teacher (Bartell, 2005). ${ }^{1}$

The Faculty of Education at Brock University and the Ontario College of Teachers (the self-regulatory body for the teaching profession) came together to create a teacher induction project as a novel process to not only support new teachers but to raise

\footnotetext{
${ }^{1}$ The conceptual and contextual framework, as well as the methodology section of this paper is derived in large part from Author, Author, Goldblatt, and Smith (in review).
} 
their consciousness about what it means to be a teacher-leader. An invitation was extended to school boards within the Golden Horseshoe Learning Consortium. The District School Board of Niagara, the Niagara Catholic Board of Education, the Hamilton-Wentworth District School Board, the Hamilton-Wentworth Catholic District School Board and the Grand Erie District School Board all contributed personnel and resources. Each school board selected two beginning teachers (in first to third years) and two mentors to participate in a series of workshops developed by OCT and Brock.

The teacher induction project identified the following specific objectives:

- To enhance teacher induction and mentorship practices in Ontario

- To model a partnership approach to induction with district school boards

- To support the induction of beginning teachers by using professional learning processes that include dialogue, reflection, inquiry and collaboration

Although teacher induction programs vary in their composition given the unique contexts of each province and state, the fundamental components of effective programs include a formally established mentor/beginning teacher pairing (Ingersoll \& Kralik, 2004), consistent professional development that is relevant to the needs of new teachers (Author, 2007), release time, and opportunities for novice teachers to network with other new and experienced colleagues (Hirsch, 2006; Wilbur \& Zepeda, 2004). Structuring time for discussion and collaboration between new and mentor teachers significantly enhances new teacher development (see, for example, Association for Supervision and Curriculum Development, 2004; Smith \& Ingersoll, 2004). Fulton, Yoon, and Lee (2005) suggest that,

if teachers are to meet the needs of their students in the $21^{\text {st }}$ Century, we must think about planning and then studying induction programs based on multiple goals, including building teacher knowledge and professional skills; integrating new teachers in the teaching community... and encouraging dialogue that supports best practice. (p. 22, as cited in Nielsen et al., 2006).

\section{The Ontario Context}

In Canada, education is the responsibility of each province's ministry of education (with the exception of First Nations schools that are governed federally). The Ontario Ministry of Education's New Teacher Induction Program (NTIP) is considered "the second step in a continuum of professional development for teachers to support effecting teaching, learning, and assessment practices, building on and complementing preservice education programs" (NTIP, 2006, p. 5). Among the objectives of NTIP is to provide full-year support for new teachers that ideally complements their learning from the faculty of education while developing the essential aptitudes and knowledge that will contribute to their effectiveness as a classroom teacher in Ontario schools.

\section{The Teacher Induction Project: Theoretical and Pragmatic Contexts}

The partnership that included Brock University's faculty of education, the Ontario College of Teachers, and six school boards across the Golden Horseshoe Learning Consortium in southern Ontario agreed on the importance of supporting new teacher practice and enhancing their leadership capacities. Supporting new teacher development through the design of collaboratively constructed processes framed on practice and ethical standards extended practitioners' knowledge and enhanced teaching practice. The process fostered the leadership capacities of individual participants within these learning 
communities (Author \& Smith, 2006). Timely and relevant professional support for new teachers is cited as a significant factor in not only retaining teachers (Johnson, 2004; Wilkins \& Clift, 2006), but in contributing to their emotional development (Bullough \& Draper, 2004), enhancing their satisfaction with the role of teacher, and most significantly, in improving pedagogical practice to improve student learning (Howe, 2006).

Given that the research has informed the fact that new teachers' roles are becoming more complex, this teacher induction project was conceptualized to enable new teacher participants to self-affirm their professional capacities as autonomous and collaborative lead learners in their schools (Author \& Smith, 2006). It provides a framework for educators to illuminate the underlying values of their professional roles and their leadership potential given the often daunting responsibility of supporting student learning.

It was imperative to situate the teacher induction project so that it was not only responsive to the research on new teacher development, but relevant to the Ontario context. As a result, new teacher participants were introduced to critical inquiry while having various opportunities to nurture what Feinman-Nemser (2001) refers to as 'the habits of critical colleagueship.' The induction project facilitators encouraged professional interactions between teacher colleagues where new teacher issues and concerns were identified, discussed, and reflected upon to enhance their understanding of themselves as professional teachers (see, also, Flores, 2006). This project reconceptualized teacher induction practices through its focus on new teachers' potential to self-affirm their respective roles as critically conscious teacher leaders and practitioners. The project recognized the importance of positioning teachers' knowledge, regardless of their status as either protégés or mentors, in a context-based and reflective environment (see Wang, Odell \& Strong, 2006) whereby their inquiry skills and constructive responses could illuminate their potential as teachers and leaders.

\section{Teacher leadership}

Although the focus of leadership has traditionally been discussed in terms of school principals (Goleman, Boyatzis, \& McKee, 2002; Hargreaves, 2005) the interest in concepts related to distributed teacher leadership is growing (Crowther, Kaagan, Ferguson, \& Hann, 2002; Elmore, 2006; Katzenmeyer \& Moller, 2002). Research has brought to light that teacher leadership consists of an individual's professional and active engagement to improve teaching and learning within the school organization (Lambert, 2002). Teacher leaders are critical and reflective practitioners who contribute to collaborative school organizational cultures (Little, 1993). This interest in teacher leadership capacity has fashioned varying interrelated notions of diverse, cultural, and transformational leadership (Bolman \& Deal, 2003; Fletcher \& Kaufer, 2003; Leithwood, Jantzi, Earl, Watson, Levin, \& Fullan, 2004). As an outcome of this interest there has been a greater emphasis upon the relationship between leadership and sustainability as these factor into school improvement. Elmore (2000; 2003; 2006) to name only one, defines distributed leadership in schools as transcending organizational hierarchies to exercise individual teacher agency. Hargreaves and Fink's (2003) leadership research also has implications upon teacher induction practices:

In a world of high expectations, rapid change, and a youthful profession in the first decades of the 21 st century, teachers cannot be merely the targets of other 
people's leadership. Instead, they must see themselves as being - and be encouraged to be - leaders of classrooms and of colleagues from the moment they begin their careers. (p. 700)

The literature suggests that teacher leadership is manifested in multiple identities (Fullan, 1993) that vary from the formal recognized roles in the organizational hierarchy of schools to the more informal (Bascia, 1997; Harrison \& Lembeck, 1996; Leithwood \& Jantzi, 2000) as alluded to in the outcomes of this project. Teacher leadership includes teachers' capacities to constructively engage in purposeful, broad-based learning in the school community whereby knowledge is sustained within meaningful relationships between individuals (Lambert, 2002). It includes teachers' proficiency to reflect upon their contributions in light of the shared beliefs within the school organizational culture (Lambert, 1998). Teacher leadership includes functioning in a collaborative context where all educators are committed to improving the learning of students (Little, 1993). The capacity to exercise teacher leadership, according to Crowther, Hann, and McMaster (1999), entails both professional qualities (such as networking skills) and processes of professional learning in a trusting environment.

\section{Methodology}

\section{Participants}

Two new and two-mentor teachers from each of the six boards of education voluntarily participated in the project. Each school board NTIP coordinator recommended potential participants. New teacher participants' teaching experience ranged between 1 and 3 years, with a mean of 1.8 years. Their teaching responsibilities ranged from grades 1 to 8 . New teacher participants taught in different schools across their school boards, and represented varied socio-economic student demographics. Four of the new teacher participants were male and 7 female. The mentor teacher participants served in the capacity as mentor between 1 and 2 years, with the mean mentoring experience being 1.2 years. The mentors did not teach in the same school as the new teacher participants, nor did they serve as their mentor. Mentors, like the new teacher participants, taught in schools that represented varied socio-economic student demographics. Three mentors were male, and 9 female. The participants served as a cross-representation of school boards in southern Ontario. The new teachers participated in two full-day sessions in November. Mentor teachers attended a one day session in January, while both new and mentor teachers participated in a joint session in March of the same academic year.

\section{Data Collection}

Data triangulation was factored in both the collection and analysis stages. To begin, both the new and mentor teacher project participants engaged in numerous written critical reflections on various issues confronting new teachers and on developing meaningful support for new teachers. Each reflection was prompted by the project facilitators at strategic intervals to encourage independent participant responses and opportunities to share perspectives in light of the larger group. Sample reflection topics included:

- What issues do new teachers / mentors face? 
- Identify a new insight or key learning that occurred as a result of this topic of discussion.

- What impact did the case-writing process have on you as a new / mentor teacher?

- What were the benefits of your reflections on your own practice as a new / mentor teacher?

Second, throughout the 4-day project sessions participants wrote their viewpoints on charts to collectively reflect and discuss the impact of certain topics at pivotal junctures during the work with cases.

Last, structured virtual interviews of approximately 50 minutes involved a set of scripted questions that were posted in an electronic site and made exclusive to project participants. Participants were invited to express their thoughts to the various questions over a 3-day period. The virtual interviews were conducted 4 weeks after the delivery of the final project session. The on-line interview protocol invited response to a range of questions related to their participation in the project and its influence upon their teaching and learning paradigms, their work with colleagues, and their own professional development as new teachers. Sample questions included:

1. As a new teacher, what would you identify as your professional development needs?

2. The project presenters stressed community from the first activity (titled "Community Builder") to the closing activities. How effective were these activities in building community? How important was this to your experience of the workshop?

3. You were often asked to reflect on your teaching experiences and your images of teaching. How valuable were these opportunities for reflection? Compare the value of reflection to the value of teaching strategies or curriculum oriented professional development.

4. The study of case studies was a critical component of the workshop. How enriching were the case study and follow-up activities? How have they informed your practice?

5. During the joint session with new teachers and teacher mentors, you worked closely with the mentors discussing and crafting some of the cases written during your first two-day session. How valuable was this experience? Did you feel any tensions during this process? Was this process useful in terms of your understanding of teaching?

6. Looking back on your experience during these sessions - and in the time since-please comment on the value of these sessions in your professional development as a new teacher.

7. How would you compare these sessions to other professional development you have received?

Participants' responses to the virtual on-line interviews were posted throughout the 3-day life of the virtual site. This virtual site was purposefully designed to allow the new and mentor teacher participants various opportunities to juxtapose their reflections with those of the other participants. There was sufficient flexibility for individuals to comment beyond the scope of the questions. 


\section{Data analysis}

The research team, well-versed in qualitative measures, cross-checked the data and triangulated the results to increase the study's validity and reliability (Miles \& Huberman, 1994).

The study's qualitative methodological approach derived from the principles of grounded theory. According to Strauss and Corbin (1990) grounded theory does not predict outcomes and instead is a methodical approach to data reduction that involves the emergent codes and categories that are grounded in the data. Grounded theory is predominantly qualitative and highly applicable to educational and sociological research due to the fact that its data is grounded in participants' observations (Chiovitti \& Piran, 2003; Kennedy \& Lingard, 2006). The process of data analysis within this qualitative tradition is significantly different from those methodologies that describe participants' realities with little input from the researcher (Glaser, 1993; Weiss \& Lloyd, 2002). The research design that evolved as part of this process considered both Eaves's (2001) synthesis of various grounded theorists (including Charmaz, 1983; Chesler, 1987), and the work of Glaser (2001) and Glaser and Strauss (1967).

Data derived from this study were selectively coded and constantly compared. Initially, the open coding process distinguished discrete concepts (basic units of analysis) and the properties respective to each concept. Phrases that were considered key were captured in the participants' own words and used in the line-by-line examination of each participant's responses (Chesler, 1987). The concepts were translated into a discussion of observations resulted in an analysis of the data on a higher conceptual level (Orona, 1997). In this light, data analysis resembled "a discussion between the actual data, the created theory, memos and the researcher" (Backman \& Kyngas, 1999, p. 149; see also Strauss \& Corbin, 1990). The process of theoretical sampling after the analyses of participants' reflections and scripted chart notes identified various preliminary hypotheses that emerged in the data. The virtual focus group interviews allowed for additional probing and for the conceptual saturation of the core categories being presented. The data themselves enable the pattern. The researcher, then, must exercise the patience to enable that which enables and hence allow the voices of the participants to materialize. Having said this, the researcher is obligated to resist all temptations to shape the findings and lean towards more traditional forms of qualitative research methodologies. (Author, 2007) The study accounted for the rhetorical construction and frames of references employed by the participants themselves in terms of the manner whereby language impacts perception to create versions of reality (Avdi, 2005; Johnstone \& Frith, 2005). The discourse that was representational of the codes, properties and categories emerging from the data is cited in the paper.

\section{Outcomes and Implications}

The inductive approach adopted throughout the analysis resulted in the emergence of an extensive series of interrelated codes and their respective properties. These codes were saturated into two core categories described as 'new teacher leadership: making meaningful contributions' and 'new teacher leadership: reflection and action.' 


\section{New teacher leadership: making meaningful contributions}

New teacher participants discussed how their participation in the induction project "opened [their] eyes to new perspectives." The dialogue sustained throughout the project's duration afforded new teachers opportunities to, as one participant described, "discuss important and relevant issues with my peers," and as another suggested, "there was immense satisfaction to be gleaned from the controlled sharing of ideas and consensus." On several occasions participants took note of how they perceived their contributions as novice teachers as being meaningful to the collective learning of their peers. Participants often shared how they "felt good to get and give feedback" and by exercising their agency as teacher professionals, were in fact affirming their teacher leadership capacities. Discussion amongst participants, and particularly between novice teachers, was typically described as "fantastic hours of learning and sharing." New teacher participants recognized their steep learning curve in many matters related to teaching and learning, but more significantly for the purpose of this discussion, also commented upon feeling "affirmed" in their proficiency to reciprocate advice and direction to colleagues.

In many respects the new teacher participants refused to be what Hargreaves and Fink (2003) refer to as "the targets of other people's leadership" (p. 700). This is not to suggest that new teacher participants perceived themselves as usurping the formally recognized positions of additional responsibility in their schools, nor did they suggest their unwillingness to take direction from school leaders. Instead, the outcomes of the induction project address a component of leadership that is seemingly all too often ignored in the literature - new teacher leadership. One new teacher participant's comment was particularly reflective of the rest: "I don't have experience [but] I do come to the table with solutions even though I am a beginning teacher." There was a willingness throughout the discussions for new teacher participants to make their voice heard and reciprocate ideas, support, and resources that were beneficial to other colleagues. Unique to these outcomes are participants' reflections that both complement and extend the existing literature on distributed, diverse, and transformational leadership paradigms (see for example, Fletcher \& Kaufer, 2003; Gronn, 2002; Leithwood, Jantzi, Earl, Watson, Levin, \& Fullan, 2004) in terms of the informal roles that new teacher participants themselves perceive to be assuming in contributing to the social, cultural, and academic influences within their school organizations (see as well, Foster, 2004; Yukl, 1999). One participant's comment was indicative of several others when she stated that the induction project facilitated her "connection with other new teachers [and that she] will make a contribution to the induction program" in her school board.

Furthermore, Crowther, Kaagan, Ferguson, and Hann's (2002) conclusion that teachers need to feel empowered to enact their individual leadership agency resonated in the voices of the new teacher participants from this project. Participants shared how they felt "less alone and empowered" to make meaningful contributions to their peers, and it was this sense of empowerment that fueled their motivation to further extend their leadership capacities beyond their own classrooms and into the school at large. One individual suggested that the induction project "offered a new window" from which he could base a more profound appreciation of his leadership influence. A different participant supported this notion in her realization that "my opinions and views are 
valuable," while a third new teacher felt compelled to suggest that "each new teacher added to the teaching potential in the room."

\section{New teacher leadership capacity: Reflection and action}

Elmore (2003) suggests that the concept of new teacher leadership is often perceived as a counter-cultural reality in public schools. Teacher leaders are described as "self-driven, flexibly developed [and] connected to teaching and learning" (Hargreaves \& Fink, 2006, p. 167). Teacher leaders also demonstrate, according to the literature, an ability to reflect upon their endeavours (Lambert, 1998; 2002). Participants from this research project consistently commented upon the "importance [of] taking time during a busy schedule to reflect and renew oneself," especially in regards to genuinely "reflecting on practice." Particularly noteworthy was new teacher participants' focus on reflection as a means of enhancing their practice and fostering student learning. As one individual stated, his participation in the project "showed how reflection on your past [experiences] can help you deal with" related circumstances in the classroom. Similarly, another new teacher participant described how the project "helped me see my role as an educator...to reflect, synthesize, gather, and use all available experiences for the betterment of our students."

New teacher participants recognized the pivotal role of reflection to improve practice, sustain their contributions, and in turn, validate their leadership influence in and beyond their own classrooms. While it may be true that new teachers experience varying levels of support, dependency, and autonomy as novice professionals (Achinstein \& Villar, 2002; Strong \& Baron, 2004), it is interesting that all of the participants in this study shared their intent to act upon their reflection and exert their leadership influence. One individual took it upon himself to summarize the intentions of the group in stating that the reflection emanating from the project illuminated the importance of new teachers "taking the bull by the horns." Participants claimed to discover "the wonderful potential we all have as a teaching community" and made numerous references to how their unique attributes, skills, and characteristics were in fact leadership capacities that could influence student development and learning. Time and again participants suggested that it is imperative to their professional development that they "trust [them] selves" to exercise their leadership capacities. Participants commented that the opportunities to reflect and deconstruct their practice and the circumstances of their peers left them "feeling as though [their contributions] were making a difference."

Also, as the induction project evolved, participants noted how their contributions to students and to the school community closely resembled those more experienced colleagues and school administrators whom they described as the "leaders in their schools." Various new teacher participants suggested that these school leaders were "involved and connected to kids," "making genuine contributions to the school," and had "high standards for student learning." In a similar light, participants perceived themselves as being willing to "share valuable ideas" with colleagues, as "enthusiastic to get involved," as being "available for all kids," and as genuinely appreciating "the importance of contributing to the community." Connections were drawn between the spheres of teacher leadership influence as it is enacted by their more experienced colleagues, and as they manifest it as new teachers. As Lambert (2002) attests and as the experiences of the new teacher participants support, leadership influence extends beyond formally recognized roles in the school hierarchy and is more representative of an 
individual's active engagement to improve student learning and development within the school organizational culture. This new teacher's reflection was typical of others: "I love teaching. I think that it is one quality that new teachers bring to the profession - they are not tired [and] are willing to take on many tasks." They are, thus, willing to exercise their leadership capacities. As Katzenmeyer and Moller (2001) recommend, new teachers deserve to be recognized for their potential to assume leadership roles.

\section{Conclusion}

In Ontario, the implementation of the New Teacher Induction Program (NTIP) 2006 was a proactive step towards improving the experiences of new teachers and, in turn, the learning of their students. Preliminary evidence suggests that this program has been well received by Ontario educators, particularly as school boards were able to adapt the program to suit local needs (Kane, Siam \& Conner, 2008).

The results of our research indicate that induction programs can be particularly effective when they use professional learning processes such as dialogue, reflection, inquiry and collaboration. These inquiry processes helped participants reflect on their experiences and draw on their critical skills to work through authentic educational challenges. As a result, the new teachers began to see themselves as agents of learning and teacher leaders. By incorporating inquiry processes into teacher induction programs, school districts can both affirm the abilities of new teachers and encourage their development as teacher leaders. 


\section{References}

Achinstein, B., \& Villar, A. (2002). The politics of the mentoring process for beginning teachers: Tensions and negotiations. Paper presented at the annual meeting of the American educational research association. New Orleans.

Association for Supervision and Curriculum Development. (2004). Characteristics of new teacher support in high- and low-income schools [Research brief]. Retrieved May 23, 2006, from http://www.ascd.org/portal/site/ascd/menuitem.03e1753c019b7.

Avdi, E. (2005). Negotiating a pathological identity in the clinical dialogue: Discourse analysis of a family therapy. Psychology and Psychotherapy: Theory, Research and Practice, 78, 493 - 511.

Backman, K., \& Kyngas, H.A. (1999). Challenges of the grounded theory approach to a novice researcher. Nursing and Health Sciences, 1, 147-153.

Bartell, C.A. (2005). Cultivating high quality teaching through induction and mentoring. Thousand Oaks, CA: Corwin Press.

Bascia, N. (1997). Invisible leadership. The Alberta Journal of Educational Research, 43(2/3), 69-85.

Bolman, L.G. \& Deal, T. (2003). Reframing organization: Artistry, choice, leadership. San Francisco, CA: Jossey Bass.

Brock, B.L., \& Grady, M.L. (1997). From first year to first rate: Principals guiding beginning teachers. Thousand Oaks, CA: Corwin Press.

Bullough, R.V. (1988). The forgotten dream of American public education. Ames, Iowa: Iowa State University Press.

Bullough, R., \& Draper, R. (2004). Mentoring and the emotions. Journal of Education for Teaching, 30(3), 271-289.

Charmaz, K. (1983). The grounded theory method: An explication and interpretation. In R.M. Emerson (Ed.), Contemporary field research (pp. 109-126). Illinois: Waveland Press.

Cherubini, L.. (2007). A personal services paradigm of teacher induction. The International Electronic Journal for Leadership in Learning, 11(6).

Cherubini, L. (2008). A grounded theory analysis of beginning teachers' experience: Illuminating leadership capacities. International Journal of Teacher Leadership, $1(1), 22-38$.

Cherubini, L. (2007). Un impianto originale per un progetto di grounded theory: Una riflessione critica. Encyclopaideia, 21, 101-118.

Cherubini, L., \& Smith, D. (2006). Supporting beginning teacher development: Induction research proposal. Teaching and Learning, 3(2), 20-24.

Cherubini, L. (in review). Broadening landscapes and affirming professional capacity: A meta-cognitive approach to teacher induction. Journal of Applied Research and Learning. 
Chesler, M.A. (1987). Professionals' views of the dangers of self-help groups: Explicating a grounded theoretical approach. Center for research on social organization, Department of sociology, University of Michigan.

Chiovitti, R.F., \& Piran, N. (2003). Rigour and grounded theory research. Journal of Advanced Nursing, 44(4), 427-435.

Cochran-Smith, M. (2006). Policy, practice, and politics in teacher education. Thousand Oaks, CA: Corwin Press.

Crowther, F., Hann, L., \& McMaster, J. (1999). Leadership for successful school innovation: Lessons from the innovation and best practice project. Report from the Innovation and Best Practice Report to DETYA, University of Southern Queensland.

Crowther, F. Kaagan, S. Ferguson, M. \& Hann, L. (2002). Developing teacher leaders. Thousand Oaks, CA: Corwin Press.

Danielson, L. (2002). Developing and retaining quality classroom teachers through mentoring. Clearing House, 75(4), 183-185.

Darling-Hammond, L. (2006). Constructing $21^{\text {st }}$-century teacher education. Journal of Teacher Education, 57(3), 300-314.

Duncan-Poitier, J. (2005). Teacher mentoring and induction. New York: New York State Education Department, Office of Teaching Initiatives.

Eaves, Y.D. (2001). A synthesis technique for grounded theory data analysis. Journal of Advanced Nursing, 35(5), 654-663.

Elmore, R.F. (2006). Breaking the cartel. Phi Delta Kappan, 517-518.

Elmore, R.F. (2000). Building a new structure for school leadership. Washington, D.C.: The Albert Shanker Institute.

Elmore, R.F. (2003). A plea for strong practice. Association for Supervision and Curriculum Development, 6-10.

Feinman-Nemser, S. (2001). From preparation to practice: Designing a continuum to strengthen and sustain teaching, from http://www.tcrecord.org/Content.asp?ContentID=10824.

Fletcher, J.K. \& Kaufer, K. (2003). Shared leadership: Paradox and possibility. In C.L. Pearce \& J.A. Conger (Eds.), Shared Leadership: Reframing the hows and whys of leadership, (pp. 21-47). Thousand Oaks, CA: Sage.

Flores, M.A. (2006). Induction and mentoring (pp. 37-66). In J.R. Dangel (Ed.), Research on teacher induction. Maryland: Rowman \& Littlefield.

Foster, R. (2004). Leadership and secondary school improvement: Case studies of tensions and possibilities. International Journal of Leadership in Education, 8(4), $35-52$.

Fullan, M. (1993). Change Forces. Toronto, ON: Falmer. 
Fulton, K., Yoon, I., \& Lee, C. (2005). Induction into learning communities. Retrieved May 15, 2006, from http://www.nctaf.org/documents/nctaf.

Glaser, B.G. (1993). Examples of grounded theory: A reader. Mill Valley, CA: Sociology Press.

Glaser, B.G. (2001). The grounded theory perspective: Conceptualization contrasted with description. Mill Valley, CA: Sociology Press.

Glaser, B. G., \& Strauss, A. (1967). The discovery of grounded theory: Strategies for qualitative research. Chicago: Aldine.

Goleman, D. Boyatzis, R.E. \& McKee, A. (2002). Primal leadership: Realizing the power of emotional intelligence. Boston: Harvard Business School Press.

Gronn, P. (2002). Distributed leadership. In K. Leithwood \& P. Hallinger (Eds.), Second International Handbook of Educational Leadership and Administration (pp. 653-696). Dordrecht, Kluwer.

Hargreaves, A. (2005). The changing world of leadership. Kappa Delta Pi, 69(2), 101110.

Hargreaves, A. \& Fink, D. (2006). Sustainable leadership. San Francisco, CA: Wiley.

Hargreaves, A., \& Fink, D. (2003). Sustaining leadership. Phi Delta Kappan, 693-700.

Harrison, J.W., \& Lembeck, E. (1996). Emergent teacher leaders, in G. Moller \& M. Katzenmeyer, (Eds.), Every Teacher is a Leader: Realizing the Potential of Teacher Leadership. San Francisco, CA: Jossey-Bass.

Hirsch, E. (2006). Recruiting and retaining teachers in Mobile, Alabama: Educators on what it will take to staff all classrooms with quality teachers. Chapel Hill, NC: Center for Teaching Quality.

Howe, E.R. (2006). Exemplary teacher induction: An international review. Educational Philosophy and Theory, 38(3), 287-297.

Ingersol, R.M., \& Kralik, J.M. (2004). The impact of mentoring on teacher retention: What the research says. Denver, CO: Education Commission of the States. Retrieved May 19, 2006, from http://www.ecs.org/clearinghouse/50/36/5036.htm.

Johnson, S.M. (2004). Finders and keepers: Helping new teachers survive and thrive in our schools. San Francisco: Jossey-Bass.

Johnstone, L., \& Frith, H. (2005). Discourse analysis and the experience of ECT. The British Psychological Society, 78, 189-203.

Kane, R., Siam, H., \& Conner, M. (2008). Evaluation of the Ontario new teacher induction program: One size does not fit all. American Educational Research Association, New York, March 2008.

Katzenmeyer, M. \& Moller, G. (2001). Awakening the sleeping giant: Helping teachers develop as leaders. Thousand Oaks, CA: Corwin.

Kennedy, T.J., \& Lingard, L.A. Making sense of grounded theory in medical education. Medical Education, (40)2, 101-108. 
Lambert, L. (1998). Building leadership capacity in schools. Alexandria, VA: Association for Supervision and Curriculum Development.

Lambert, L. (2002). Framing reform for the new millennium: Leadership capacity in schools and districts. The University of Manitoba Publications.

Leithwood, K., \& Jantzi, D. (2000). Principal and teacher leadership effects: A replication. School Leadership and Management, 20(4), 415-434.

Leithwood, K. Jantzi, D. Earl, L. Watson, N. Levin, B. \& Fullan, M. (2004). Strategic leadership for large scale reform: The case of England's national literacy and numeracy strategy. School Leadership and Management, 24(1), 57-79.

Little, J. W. (1993). Teachers' professional development in a climate of educational reform. Educational Evaluation and Policy Analysis, 5 (2), 129-151.

Miles, M.B., \& Huberman, A.M. (1994). Qualitative data analysis: An expanded sourcebook. Thousand Oaks, CA: Sage.

Nielsen, D.C., Lundmark, Barry, A.L., \& Addison, A.B. (2006). A model of a newteacher induction program and teacher perceptions of beneficial components. Action in Teacher Education, 28(4), 14-24.

Ontario Ministry of Education. (2007). New teacher induction program. Toronto: Author.

Orona, C.J. (1997). Temporality and identity loss due to Alzheimer's disease. In A. Strauss \& J. Corbin (Eds.), Grounded theory in practice (pp. 171-196). Thousand Oaks, CA: Sage.

Renard, L. (2003, May). Setting new teachers up for failure or success. Educational Leadership, 62-64.

Smith, T.M., \& Ingersoll, R.M. (2004). What are the effects of induction and mentoring on beginning teacher turnover? American Educational Research Journal, 41(3), 681-714.

Strauss, A., \& Corbin, J. (1990). Basics of qualitative research: Grounded theory procedures and techniques. Newbury Park, CA: Sage.

Strong, M., \& Baron, W. (2004). An analysis of mentoring conversations with beginning teachers: Suggestions and responses. Teaching and Teacher Education, 20, 47-57.

Wang, J., Odell, S.J., \& Strong, M. (2006). Conversations about teaching (pp. 125-144). . In J.R. Dangel (Ed.), Research on teacher induction. Maryland: Rowman \& Littlefield.

Weiss, M.P., \& Lloyd, J. W. (2002). Congruence between roles and actions of secondary special educators in co-taught and special education settings. Journal of Special Education, 36(2), 58-69.

Weiss, E.M., \& Weiss, S.G. (1999). Beginning teacher induction. ERIC Digest, 1-5.

Wilbur, M.L., \& Zepeda, S.J. (2004). How do we know we're making a difference? Supporting and evaluating induction programs that promote novice teacher development and student achievement. Unpublished manuscript, University of Georgia, Athens. 
Wilkins, E.A., \& Clift, R.T. (2006). Building a network of support for new teachers. Action in Teacher Education, 28(4), 25-35.

Yukl, G. (1999). An evaluation of conceptual weakness in transformational and charismatic leadership theories. The Leadership Quarterly, 10(2), 285-305. 


\section{The following we envision as a textbox or sidebar:}

\section{Resources for Teacher Induction}

In addition to researching the induction needs of new teachers, the partners in this project also committed to developing practical resources for teacher induction. The resource kit, titled Learning from experience: Supporting beginning teachers and mentors, contains five booklets:

Booklet 1: Facilitator's guide.

Booklet 2: Using the case method in induction.

Booklet 3: Exploring professional practice through vignettes.

Booklet 4: Implementing a professional learning session.

Booklet 5: Research summary.

These booklets will be available in February 2009 in PDF format on the Ontario College Teachers website (www.oct.ca) and Brock University's Faculty of Education website (www.brocku.ca/fed/). These booklets will also be available in French. 